\title{
The Research on Relationships between Political Connection and Corporate Performance in China: Top Management Team's Human Capital as the Moderator
}

\author{
Jing Liu \\ School of Business and Administration, Henan University of Engineering, Zhengzhou 451191, \\ China \\ Email: liujing1007@163.com
}

Keywords: non market competition strategy; political connection; performance; human capital, top management team(TMT); depth of human capital; width of human capital

Abstract: This paper not only conducted effects of political connection on corporate performance, but also testified the moderate role of the depth and width of the TMT to the relationship between political connection and performance in the agricultural market, which is close to perfect competition. It is found that the interaction between TMT's width and political connection positively moderated the relationship between chairman's political connection and performance. But their interactions will decrease the company's performance. Political connection played some effects in agriculture market under the background of China's social culture and cognition, but it didn't have significant influence on company's performance. The government should regulate the political connection and increase the transparency of information. From the internal governance of enterprises, the corporation should keep regular communication with the government, and control the cost of political connection under the law.

\section{Introduction}

Porter's "five forces model" and the theory of resource dependence explain market competition by passive acceptance of realism. However, because of defects of its imperfect explanation, non-market competition strategy emerged. Political association is an important way for enterprises to implement non-market competition strategy, but its formation is subject to certain situation, especially the influence of culture, cognition and other factors on actors. The consciousness of "official standard" and "relationship" in Chinese society has far-reaching influences. Therefore, many entrepreneurs strive for the membership of the representatives of the National People's Congress or the members of the CPPCC, which is not only the competitive strategy they have taken on the basis of cognition and judgment of the external environment, but may also contain the value preference and value orientation of the individual executives.

Scholars have studied relationships between political connection and corporate performance, and formed the following opinions. Faccio (2002) believed that political relevance had a positive effect on enterprise performance. It was the reason that state-owned enterprises could obtain orders and 
tax relief through political connections, finally forming the to pressure to their competitors, especially in the areas with imperfect system, in which political connection could partly replace the system and help the enterprise to improve the value (Gao and Wang, 2014). Other scholars believed that political relevance had a negative effect on enterprise performance. The possible reason was that political association would cause transaction costs and ineffective investment, resulting in performance decline(Claessens et al., 2008).

Some scholars believed that the political relevance had no significant impact on enterprise performance. Although enterprises were state-owned, political association had no effect on corporate performance, which was result of the professionalism of that company(Mansor, 2018).

Obviously, different scholars have diverse conclusions about relationships between political connection and corporate performance. This may be due to the following reasons:

From the sample selected by the scholars, most of the results are based on samples of private enterprises, state-owned enterprises or enterprises in Shanghai and Shenzhen stock markets, which helps us to understand the role of political connection from category attributes or overall. Scholars found that political relevance had an substitute role to market mechanism (Gao and Wang, 2014), but it was worth continuing to discuss whether political connections could play its alternative role under different market structures. Therefore, this paper takes the agricultural leading listed companies as an example to study the influence of political connection on enterprise performance under the competitive market, so as to provide a reference for the enterprise to use the political connection to deal with the market competition strategies.

Additionally, most of researches are based on resource dependence theory and stakeholder theory, from the paradigm of realism to understand and study the impact of political connections and their effects. Moreover, scholars' researches mainly focus on the directors, general managers and CEO from the perspective of the subject of political connections, but they do not pay much attention to the interaction between executive team and the political related subjects. Through the research on the interaction, it is helpful for the enterprise and the top management team(TMT) to make a clearer orientation to the strategy, and offers some implications for enterprise governance.

\section{Literature review and research hypothesis}

The political connection is to build an environment conducive to enterprise's development by the chairman as the main actor, and then forms an interactive relationship with the government, which is constrained by the chairman's values, knowledge, experience and the current situation of the enterprise. Political connection is not only a continuation of the thought of "relationship" and "official standard" in Chinese traditional culture, but also a practice mode of non-market competition strategy chosen by enterprises. The government's allocation of resources and system construction can influence enterprises, market and society from time and space. In order to test the relationships between political connection and business performance and the moderating role of TMT's human capital, the author set up the following theoretical models and hypotheses.

\section{1 influence of political connection on enterprise performance}

(1) Political connection helps enterprises to get policy resources. The interaction between entrepreneurs and government officials will not only help enterprises obtain more preferential tax rates and preferential government procurement orders (Faccio, 2002), but also make it easier for political related enterprises to obtain financial subsidies for R\&D innovation. Rent-seeking may eventually lead to a crowding out of R\&D spending, which decreases technology subsidies from government, especially for companies in high-corruption provinces (Cai et al., 2017).

(2) Political connection contributes to corporate financial integration and asset maintenance. In 
terms of reducing the cost of financing, political connection can adjust companies better, both in state-owned and private companies, and political connection will help them to get bank loans (Peng et al., 2013).In addition, political connection is positively related to the performance of mergers and acquisitions, which can be used as an alternative mechanism for legal protection to protect property rights of state-owned enterprises from the government damage (Pan et al., 2008).

(3) Political connection helps to reduce the risk of strategic choice. Through communication with government officials, potential risks of emerging industries can be avoided by political related enterprises. Even if the government has issued an encouraging policy, political related enterprises based on more full industry information choose to continue to profit in a way that does not enter( $\mathrm{Li}$ et al., 2013). In addition, from the perspective of internationalization strategy, political connection of Chinese private listed companies has a significant role in promoting the depth of the internationalization strategy, and the depth of political connection of private enterprises can obviously improve the short term performance of the enterprise(Deng et al., 2014).

Therefore, by establishing political connection with the government, Chinese enterprises can form the deeper understanding of the society, industry and market, thus making more reasonable market competition strategies and strategies to improve the performance of the enterprises. Moreover, this article puts forward the following hypothesis:

H1: political connetion has a positive impact on enterprise performance

\subsection{Moderating role of TMT's human capital}

(1) The moderating effect of TMT's breadth on the relationship between political connection and firm performance

The breadth of TMT refers to the social relations integrated by the executive team members based on their own quality, cognition, external resources and environmental interaction, information, opportunities and so on. It is the influence and the way of radiation that the individual spreads outward from the enterprise. The top management team members are nominated by the chairman and identified by the board of directors, which reflects impacts of the chairman's cognition on the final nomination of candidates. Therefore, the composition of TMT is essentially a subjective construction based on cognition of enterprises and market environment. Li and Zhang (2007)believed that not only political network and professionalism of professional managers would contribute to enterprise performance, but also even the experience of professional managers was becoming more and more important. Additionally, the chief executive of a government bank with political background could use their political power to influence the bank's loan decisions, thus relaxing the loan standards and gaining private interests(Chen et al., 2018).

From the perspective of political network of professional managers, the background and experience of the people's Congress, membership of the Political Consultative Conference and industry association are important embodiment of the depth of TMT's human capital. In addition, the heterogeneity of work experience of the executive team members can make up for differences caused by personal ability and their way of thinking, strengthen the consistency within the team, increase the breadth of the cognition of the problem, and reflect the complementary effect of the executive team (Amason and Sapienza, 1997). Moreover, when executives carry out inter organizational exchanges and cooperation, divergent channels and communication methods of TMT

can help the organization expand several channels and resources, and reflect the synergy effect of the team. Therefore, we get the hypothesis:

H2: the breadth of TMT's human capital positively moderates the effect of corporate political connection on corporate performance. 
(2) The moderating effect of TMT's human capital depth on political connection and business performance.

The depth of TMT's human capital is deeply constructed basing on the internal interaction of the enterprise, such as knowledge and learning. Enterprise management needs to rely on soft culture and hard strength to put forward, and the construction of knowledge, learning, professional skills and enterprise culture can not only form important intangible assets, but also help executives to refine enterprise strategy by relying on personal charm, expert power and legal authority under certain circumstances. The profession of executive human capital helps to build internal competitiveness suitable for the external environment of enterprises, such as production, sales and innovation capabilities. Therefore, a high proportion of senior management team with profession, technology and sales background can not only enhance the R\&D ability and innovation consciousness of the enterprise, but also enhance its ability to grasp the market opportunity. Especially the top-down learning mechanism, cognitive mode and interaction mode promoted by TMT are important ways to influence the sustainable development of enterprises and employees. From the perspective of the division of labor, the depth of the human capital of TMT is intrinsic. Under the constraints of time and energy, the depth of the executive human capital has obvious counterforce to the extrovert of the enterprise's political connection. Therefore, we get the hypothesis:

H3: the depth of TMT's human capital negatively moderates the effect of political connection on corporate performance.

\section{Empirical research}

\subsection{Sample selection and data sources}

This study used data from 2009 to 2013 for listed agricultural leading companies in Shanghai and Shenzhen A shares as observation samples, excluding ST enterprises in the sample. By collecting 5 years' data of 30 leading agricultural listed companies, we collected 150 observational cross sections and 3000 observation variables. The reason why we choose the leading agricultural listed companies is mainly due to the following two reasons. On the one hand, the market of agricultural products is close to the perfectly competitive market theoretically. On the other hand, there are some problems that depend on the government to solve problems in agricultural products market, including market access system, government subsidies, etc. The financial data of enterprises came from the annual report published by the listed company. The political connection data was partly derived from the financial statements of enterprises, and the other part of the data was from the manual collection of the documents issued by the government. What's more, in order to avoid multicollinearity between variables, data was standardized.

\subsection{Variable definition}

Dependent variable: the author selected ROE and Tobin_Q values as the dependent variable of the model, and took ROA as the dependent variable of the robustness in the test model.

Explanatory variables: there were differences in the definition of political connection variables. Scholars (Faccio, 2002, Pan et al., 2008) took the chairman as the main body of political connection, and assigned the variables of 1 or 0 according to "yes" or "no" respectively from two levels of the central and local levels, including the assignment, award winning or serving as a two conferences and members of the CPPCC. Then the total value of the political connection was summed up.

Moderator variables: the author used HCD and HCW to represent the depth and breadth of human capital in TMT, respectively. The concept of TMT was defined as the management team 
made up of directors, supervisors and senior managers published in the annual reports of listed companies. The depth of the human capital in TMT (HCD) was to reflect the use of knowledge, experience and skills to build the specific human capital of senior executives. HCD was measured by the addition of two indicators, including the proportion of master and above, and the proportion of technical background and sales managers in the company (Wang et al., 2014).

The human capital breadth of the TMT (HCW) mainly represents the perception of executives based on their own ability. It reflects the TMT's resource integration ability cross organization and industry from the horizontal dimension. The relationship between the TMT and the outside mainly exists in enterprises, which act as the center to radiate and produce interaction with industry association, government agency, and the upstream and downstream enterprises in the industry. Therefore, TMT's human capital breadth was measured in the formula: HCW=A+ PR+ PS+ I $(\mathrm{HCW}=0 \sim 4)$. A represented the proportion of members of the industry association. PR represented the proportion of members of the people's Congress. PS represents the proportion of CPPCC members. I represented the proportion of employees experience with 2 or more industries.

Control variables. In order to reduce the influence of other variables' influences on target variables, the author chose 13 variables that probably affect the result as control variables, including the proportion of institutional shareholding, the proportion of staff, the proportion of sales staff, the proportion of college education and above, the concentration of equity, the balance of equity, the growth rate of operating income, the proportion of independent director, board size, enterprise scale, asset liability ratio, chairman turnover and executive shareholding ratio. The measurement methods of each variable were detailed in Table 1. 
Table 1 List of variables

\begin{tabular}{|c|c|c|c|}
\hline & Variable name & $\begin{array}{l}\text { Variable } \\
\text { symbol }\end{array}$ & Variable definition \\
\hline \multirow{2}{*}{$\begin{array}{l}\text { Dependent } \\
\text { variable }\end{array}$} & ROE & ROE & Net profit / shareholders' equity \\
\hline & Tobin Q & Tobin Q & $\begin{array}{l}\text { Tobin Q = (company's circulation stock market value }+ \\
\text { preferred stock value + liabilities net value) / total assets }\end{array}$ \\
\hline \multirow[t]{2}{*}{$\begin{array}{l}\text { Explanatory } \\
\text { variable }\end{array}$} & Political connection & PC & $\begin{array}{l}\text { Taking the political connection of the chairman as a proxy } \\
\text { variable }\end{array}$ \\
\hline & $\begin{array}{l}\text { The depth of human capital of } \\
\text { the TMT }\end{array}$ & HCD & $\begin{array}{l}\text { Measurement of executive knowledge, experience, and } \\
\text { specific skills }\end{array}$ \\
\hline \multirow{8}{*}{ Moderator } & $\begin{array}{l}\text { The width of human capital of } \\
\text { the TMT }\end{array}$ & HCW & Reflecting the ability of executives to acquire social resources \\
\hline & $\begin{array}{l}\text { Political connection * The depth } \\
\text { of human capital of the TMT }\end{array}$ & PC* HCD & $\begin{array}{l}\text { The interaction between political connections and depth of } \\
\text { TMT's human capital. }\end{array}$ \\
\hline & $\begin{array}{l}\text { Political connection * The width } \\
\text { of human capital of the TMT }\end{array}$ & $\mathrm{PC}^{*} \mathrm{HCW}$ & $\begin{array}{l}\text { The interaction between political connections and width of } \\
\text { TMT's human capital. }\end{array}$ \\
\hline & Institutional shareholding ratio & IFIN & $\begin{array}{l}\text { The sum of shareholding ratio of funds and investment } \\
\text { institutions among the ten largest shareholders. }\end{array}$ \\
\hline & $\begin{array}{l}\text { Scientific and technological staff } \\
\text { ratio }\end{array}$ & STR & $\begin{array}{l}\text { Number of scientific and technological personnel /Number of } \\
\text { employees }\end{array}$ \\
\hline & Proportion of salesmen & SR & Number of sales staff / number of employees \\
\hline & $\begin{array}{l}\text { Staffs with junior college } \\
\text { education and above }\end{array}$ & EDR & $\begin{array}{l}\text { Number of staffs with junior college education and } \\
\text { above/number of employees }\end{array}$ \\
\hline & Ownership concentration & OC & Proportion of the first largest shareholder \\
\hline \multirow{8}{*}{$\begin{array}{l}\text { Control } \\
\text { variable }\end{array}$} & Equity balance & OS & $\begin{array}{l}\text { Share ratio of the top five shareholders/ } \\
\text { Proportion of the first largest shareholder }\end{array}$ \\
\hline & increase rate of business revenue & $\mathrm{RR}$ & $\begin{array}{l}\text { (business income this year-business income last year)/business } \\
\text { income last year }\end{array}$ \\
\hline & $\begin{array}{l}\text { Proportion of independent } \\
\text { directors }\end{array}$ & DR & The number of independent directors / the size of the board \\
\hline & Board size & BS & Board members \\
\hline & Enterprise scale & ES & Logarithm of total assets \\
\hline & Asset-liability ratio & ADR & Liabilities / assets \\
\hline & Chairman changes & CEO & The change was 1 , and the unchanged was 0 \\
\hline & Executive shareholding ratio & SR & The proportion of top ten shareholders \\
\hline
\end{tabular}

\subsection{Model construction}

Considering the data of 5 years' length was similar to the cross-section data for agricultural leading companies, so we built a hybrid OLS model to fit it.

\section{Empirical results}


Table 2 Mixed OLS Regression Model

\begin{tabular}{|c|c|c|c|c|c|c|}
\hline & Model 1 & Model 2 & Model 3 & Model 4 & Model 5 & Model 6 \\
\hline $\begin{array}{l}\text { Dependent } \\
\text { variable }\end{array}$ & ROE & Tobin's Q & ROE & Tobin's Q & ROE & Tobin’s Q \\
\hline $\mathrm{C}$ & 7.41E-07 & $5.88 \mathrm{E}-08$ & $5.40 \mathrm{E}-07$ & $-5.70 \mathrm{E}-07$ & $-6.73 E-09$ & $-8.26 \mathrm{E}-07$ \\
\hline PC & $\begin{array}{c}0.058800 \\
(0.677949)\end{array}$ & $\begin{array}{c}0.107679 \\
(1.229306)\end{array}$ & $\begin{array}{c}0.205035 \\
(0.624493)\end{array}$ & $\begin{array}{c}0.520927 \\
(1.614705)\end{array}$ & $\begin{array}{c}0.456490 * * * \\
(2.107613)\end{array}$ & $\begin{array}{c}0.578924 * * * \\
(2.665321)\end{array}$ \\
\hline HCD & & & $\begin{array}{c}0.014543 \\
(0.130999)\end{array}$ & $\begin{array}{c}-0.133168 \\
(-1.220799)\end{array}$ & & \\
\hline PC* HCD & & & $\begin{array}{c}-0.157285 \\
(-0.461079)\end{array}$ & $\begin{array}{c}-0.440775 \\
(-1.314986)\end{array}$ & & \\
\hline HCW & & & & & $\begin{array}{c}0.134888 \\
(1.065454)\end{array}$ & $\begin{array}{c}0.153025 \\
(1.205292)\end{array}$ \\
\hline PC* HCW & & & & & $\begin{array}{c}-0.463891^{* *} \\
(-2.000248)\end{array}$ & $\begin{array}{c}-0.549688 * * \\
(-2.363485)\end{array}$ \\
\hline CEO & $\begin{array}{c}-0.002290 \\
(-0.031076)\end{array}$ & $\begin{array}{c}0.061514 \\
(0.826677)\end{array}$ & $\begin{array}{c}-0.007066 \\
(-0.094407)\end{array}$ & $\begin{array}{c}0.046593 \\
(0.633520)\end{array}$ & $\begin{array}{c}-0.010099 \\
(-0.137910)\end{array}$ & $\begin{array}{c}0.051795 \\
(0.705305)\end{array}$ \\
\hline OS & $\begin{array}{c}-0.070900 \\
(-0.867406)\end{array}$ & $\begin{array}{c}-0.089537 \\
(-1.084648)\end{array}$ & $\begin{array}{c}-0.068876 \\
(-0.826229)\end{array}$ & $\begin{array}{c}-0.104230 \\
(-1.272456)\end{array}$ & $\begin{array}{c}-0.066073 \\
(-0.812185)\end{array}$ & $\begin{array}{l}-0.083164 \\
(0.705305)\end{array}$ \\
\hline OC & $\begin{array}{c}0.139229 \\
(1.711517)\end{array}$ & $\begin{array}{c}-0.119674 \\
(-1.456658)\end{array}$ & $\begin{array}{c}0.134343 \\
(1.628697)\end{array}$ & $\begin{array}{c}-0.139292 * \\
(-1.718581)\end{array}$ & $\begin{array}{l}0.152373^{*} \\
(1.865796)\end{array}$ & $\begin{array}{c}-0.102998 \\
(-1.257634)\end{array}$ \\
\hline IFIN & $\begin{array}{c}0.155743 \\
(1.844211)\end{array}$ & $\begin{array}{c}0.152928 \\
(1.793059)\end{array}$ & $\begin{array}{l}0.156921^{*} \\
(1.844891)\end{array}$ & $\begin{array}{l}0.154638^{*} \\
(1.850222)\end{array}$ & $\begin{array}{l}0.132628 \\
(1.566277)\end{array}$ & $\begin{array}{c}0.124649 \\
(1.467883)\end{array}$ \\
\hline ES & $\begin{array}{c}0.365738^{* * *} \\
(3.614535)\end{array}$ & $\begin{array}{l}-0.187265^{*} \\
(-1.832510)\end{array}$ & $\begin{array}{c}0.364507 * * * \\
(3.498156)\end{array}$ & $\begin{array}{c}-0.152813 * * * \\
(-1.492489)\end{array}$ & $\begin{array}{c}0.369100 * * * \\
(3.670040)\end{array}$ & $\begin{array}{l}-0.183862 * \\
(-1.823002)\end{array}$ \\
\hline ESR & $\begin{array}{c}0.113032 \\
(1.458336)\end{array}$ & $\begin{array}{c}0.001619 \\
(0.020677)\end{array}$ & $\begin{array}{c}0.113356 \\
(1.452728)\end{array}$ & $\begin{array}{c}0.005258 \\
(0.068580)\end{array}$ & $\begin{array}{l}0.100738 \\
(1.306517)\end{array}$ & $\begin{array}{c}-0.013427 \\
(-0.173654)\end{array}$ \\
\hline BS & $\begin{array}{c}-0.160587 \\
(-1.899361)\end{array}$ & $\begin{array}{c}-0.068003 \\
(-0.796400)\end{array}$ & $\begin{array}{c}-0.153767 \\
(-1.738523)\end{array}$ & $\begin{array}{c}-0.003888 \\
(-0.044731)\end{array}$ & $\begin{array}{l}-0.170547 \\
(-2.000344)\end{array}$ & $\begin{array}{l}-0.0078742 \\
(-0.920948)\end{array}$ \\
\hline DR & $\begin{array}{l}-0.139783^{*} \\
(-1.785120)\end{array}$ & $\begin{array}{l}0.154412^{*} \\
(1.952550)\end{array}$ & $\begin{array}{c}-0.144993^{*} \\
(-1.823151)\end{array}$ & $\begin{array}{l}0.131976 * \\
(1.688830)\end{array}$ & $\begin{array}{l}-0.075054^{*} \\
\quad(-1.140370)\end{array}$ & $\begin{array}{l}0.151979 * \\
(1.911238)\end{array}$ \\
\hline RR & $\begin{array}{l}0.143754 * \\
(1.935064)\end{array}$ & $\begin{array}{l}0.072457 * \\
(0.965743)\end{array}$ & $\begin{array}{c}0.143653 \\
(1.920224)\end{array}$ & $\begin{array}{l}0.068029 * \\
(0.925435)\end{array}$ & $\begin{array}{l}0.144280^{*} \\
\quad(1.927660)\end{array}$ & $\begin{array}{c}0.074160 \\
(0.988016)\end{array}$ \\
\hline EDR & $\begin{array}{l}0.151396 * \\
(1.711743)\end{array}$ & $\begin{array}{c}-0.090667 \\
(-1.015031)\end{array}$ & $\begin{array}{c}0.152196 \\
(1.703144)\end{array}$ & $\begin{array}{l}-0.073647 * \\
(-0.838724)\end{array}$ & $\begin{array}{l}0.145158 \\
\quad(1.655678)\end{array}$ & $\begin{array}{c}-0.098142 \\
(-1.116245)\end{array}$ \\
\hline STR & $\begin{array}{c}-0.065635 \\
(-0.716030)\end{array}$ & $\begin{array}{c}0.057127 \\
(0.617080)\end{array}$ & $\begin{array}{c}-0.073670 \\
(-0.731214)\end{array}$ & $\begin{array}{c}-0.043421 \\
(-0.438602)\end{array}$ & $\begin{array}{c}-0.049483 \\
(-0.535227)\end{array}$ & $\begin{array}{l}0.077717 \\
(0.838239)\end{array}$ \\
\hline SR & $\begin{array}{c}0.062602 \\
(0.703848)\end{array}$ & $\begin{array}{c}-0.001477 \\
(-0.016448)\end{array}$ & $\begin{array}{c}0.068216 \\
(0.755175)\end{array}$ & $\begin{array}{c}0.028798 \\
(0.324445)\end{array}$ & $\begin{array}{l}0.064552 \\
(0.725266)\end{array}$ & $\begin{array}{l}-0.000127 \\
(-0.001425)\end{array}$ \\
\hline ADR & $\begin{array}{c}-0.393459 * * * \\
(-4.769222)\end{array}$ & $\begin{array}{c}-0.384921 * * * \\
(-4.619827)\end{array}$ & $\begin{array}{c}-0.395286 * * * \\
(-4.254020)\end{array}$ & $\begin{array}{c}-0.467753 * * * \\
(-5.122968)\end{array}$ & $\begin{array}{l}-0.379116^{* * * *} \\
(-4.519356)\end{array}$ & $\begin{array}{c}-0.366337 * * * \\
(-4.354656)\end{array}$ \\
\hline $\mathrm{R}^{2}$ & 0.315626 & 0.301959 & 0.316869 & 0.452544 & 0.338236 & 0.334472 \\
\hline $\mathrm{R}$ & 0.244654 & 0.229570 & 0.234687 & 0.261067 & 0.258626 & 0.254409 \\
\hline $\mathrm{F}$ & $4.447185^{* * *}$ & $4.171320^{* * *}$ & $3.855731 * * *$ & $4.290132^{* * *}$ & $4.248629 * * *$ & $4.177588^{* * *}$ \\
\hline
\end{tabular}

In table 2, the regression coefficient of each variable was estimated, and the t test value of the coefficient was in the bracket. $* * *$ represents the significance level of $1 \%$, ** represents $5 \%$ significance level, * represents $10 \%$ significance level (double-tailed test). In addition, the data of the model, which added the HCW as the moderator, was not listed in the table above, because the moderator did not pass the significance test.

From table 2, it showed that the F statistics of the 6 models were tested at 1\% significant level. From model 1 and model 2, the political connection coefficient of leading agricultural listed companies did not pass the significant test, which showed that the political connection did not increase enterprise performance. That did not verify the hypothesis H1. From model 1 and 2, it illustrated that three indicators, including enterprise scale (ES), business income growth rate (RR), and proportion of College employees or above (EDR), had positive impacts on corporate 
performance. The proportion of independent directors (DR) and asset liability ratio (ADR) played negative roles in business performance.

In model 3 and 4, the regression coefficient between political connection and enterprise performance was not tested after adding variables, including depth of TMT's human capital, interaction of human capital's depth and political connections. The regression coefficients between the two variables and the performance (ROE, Tobin 's Q) didn't pass the significance test, indicating that the two variables did not play a moderating role between political connection and enterprise performance.

It was known from model 5 and 6 that the significant coefficient of HRW variables was not tested after adding the breadth of human capital, the interaction of breadth of human capital and the political connection. And the interaction coefficient of PC* HRW was negative $(p<0.05)$, and the significant coefficient of the political association (PC) was tested under the significant level of $1 \%$, which indicated that the $\mathrm{R}^{2}$ of the model 5 and 6 was better than that in model 1 and 2 . The results show that if the TMT and the chairman carry out political connections together, it will negatively moderate the performance of the enterprise, but the effect of political connection on enterprise performance is positive.

Additionally, in order to determine the moderating effect of HCW or PC* HCW on ROE and Tobin 's Q in models 5 and 6, the author added HCW as a separate moderate to the model, and results showed that the significant coefficient of the political association (PC) was tested, and the interaction of $\mathrm{PC} * \mathrm{HCW}$ played a negative regulating effect between political connection and enterprise performance. It is worth noting that the positive impact of political connection on corporate performance and the negative moderate of PC* HCW on the effect of political connection on enterprise performance can be almost counterbalanced (see Table 2). As a result, the results of the 6 regression models showed that equity concentration (OC), enterprise scale (ES), independent director ratio (DR), growth rate of business income (RR) and asset liability ratio (ADR) had significant effects on ROE and Tobin 's Q.

\section{Robustness test}

In order to test the robustness of the model, the author examined the ROA as substitute variable for dependent variables, and obtained two models respectively, with PC as the independent variable model, and the 2 models of HCD and HCD*PC as the moderator. In the model with HCD as the moderator, F statistic was $4.577726(\mathrm{p}<0.01)$ and $\mathrm{R}^{2}$ was 0.321908 . In the model with HCD*PC as the moderator, F statistic was $4.125924(\mathrm{p}<0.01)$ and R2 was 0.331708 . However, in the above two models, the significance of the regression coefficient of PC, HCD and HCD*PC did not pass the significance test.

Moreover, the two new models, including HCW and HCW*PC as moderator, were tested respectively, and their $\mathrm{F}$ statistics and $\mathrm{R}^{2}$ were tested by significance. In the model with $\mathrm{HCW}$ as the moderator, the regression coefficient of PC was $0.474473(\mathrm{p}<0.05)$. In the model with $\mathrm{HCW}^{*} \mathrm{PC}$ as the moderator, the coefficient of $\mathrm{HCW}^{*} \mathrm{PC}$ was $-0.625208(\mathrm{P}<0.01)$.

The results of the robustness test were consistent with the regression coefficients of the independent variables and dependent variables in table 2, indicating that the model was stable.

\section{Conclusions and implications}

After the data analysis of 30 leading listed companies in agriculture from 2009 to 2013, it was found that the political connection, which was mainly engaged by the chairman, did not significantly affect the business performance in the short term. The depth of human capital or the breadth of TMT's human capital did not moderate the effect of political connection on corporate 
performance. However, the interaction between the breadth of human capital and political connection of TMT played a positive moderating role between the political connection and enterprise performance. And it played a negative role in moderating the performance of agricultural leading companies. Moreover, enterprise performance was significantly different from the absolute value of positive moderation and negative adjustment. The above results show that if the TMT is involved in political connection of the enterprise, the breadth of the human capital of the TMT can strengthen the positive influence of political connection on enterprise performance. But the political participation of the TMT may make them unable to put more effort into technical innovation, marketing innovation, etc., which is to build the core competitiveness of enterprise development, thus reduce the operating performance of companies. Therefore, enterprises still need to dig deeply from internal governance. On the one hand, enterprises should increase the scale efficiency of enterprises through technological innovation so as to improve their profitability, and increase the reserve of human capital of higher education. On the other hand, enterprises should control the proportion of independent directors and the liabilities of enterprises, thus improving the operating performance of enterprises.

The implication of this study is that political connection is not only a non-market competition strategy, but also a phenomenon in Chinese social culture. Under the agricultural market, which is close to perfect competition conditions, political connection has no obvious substitute effect on market system, and even political connection can be understood as hygiene factors of corporate performance, to some extent. In other words, it can maintain the survival and development of the enterprise, but it cannot significantly improve company performance.

But why do companies pay so much attention to political connections? The possible reason is that in the Chinese context, Listed companies also try to use political connections to gain competitive advantage, so as to avoid being marginalized in the pattern of difference order. (Fei, 1985).

This is not only the motive of direct interest, but also the social value orientation of maintaining harmonious government and enterprise relations. It may also include personal motivations for "Self-actualization" and "social acceptance" of corporate leaders. Other possible reasons are that competitive companies may adopt the same non-market competition strategy, through the recognition and judgment of the market environment. The competitive advantage formed by the enterprises that take action first will be weakened and offset constantly, and the learning effect of the competitors will lead to the equilibrium among enterprises.

The government should arrange legal and reasonable political channels for enterprises, so as to normalize political relations. At the same time, the government should keep the information transparency, including transfer payments and subsidies, and reduce the transaction costs and ineffective investment of enterprises, which can make the enterprise compete in a relatively fair market conditions to carry out the non-market strategies, so as to stimulate the enterprise vitality and promote the development of new industries.

Predictably, with China's integration with the world market in the baptism of the tide of globalization, regulating political connection is the inevitable trend of market regulation and government institutional reform, which also implies the future research direction.

\section{References}

[1] AMASON, A. C. \& SAPIENZA, H. J. 1997. The effects of top management team size and interaction norms on cognitive and affective conflict. Journal of Management, 23, 495-516.

[2] CAI, D., YANG, Z., JIANG, W. \& XU, Q. The Empirical Evidence of the Effect on the Enterprises R\&D from Government Subsidies, Political Connections and Rent-Seeking. International Conference on Management Science and Engineering Management, 2017. 499-510. 
[3] CHEN, H. K., LIAO, Y. C., LIN, C. Y. \& YEN, J. F. 2018. The Effect of the Political Connections of Government Bank CEOs on Bank Performance during the Financial Crisis «?. Journal of Financial Stability.

[4] CLAESSENS, S., FEIJEN, E. \& LAEVEN, L. 2008. Political connections and preferential access to finance: The role of campaign contributions. Journal of Financial Economics, 88, 554-580.

[5] DENG, X., XIONG, H., LI, J., HOU, J. \& WU, J. 2014. Political Connection, Internationalization Strategy, and Firm Value: Evidence from the Panel Data of Chinese Private Listed Companies. Nankai Business Review, 26-43.

[6] FACCIO, M. 2002. Politically-Connected Firms: Can They Squeeze the State? Social Science Electronic Publishing, volume 96, 369-386(18).

[7] FEI, H. 1985. Earthbound China, Beijing, SDX Joint Publishing Company.

[8] GAO, B. \& WANG, Y. 2014. Empirical Study on Relationship between Manager's Political Connection, Institutional Environment and Firm's Performance. Technology Economics, 11, 116-122,132.

[9] LI, L., GAO, H., GU, C. \& XUE, D. 2013. Research on Industrial Structure and Performance of POEs from Political Connection Perspective: Based on POEs' Data from 2005 to 2010. Nankai Business Review, 94-105.

[10] MANSOR, N. Do Political Connections Affect the Performance of Indonesian Regional Development Banks? International Conference on Tourism, Technology and Business Management, 2018.

[11] PAN, H., XIA, X. \& YU, M. 2008. Government Intervention, Political Connections and the Mergers of Local Government-controlled Enterprises. Economic Research Journal, 41-52.

[12] PENG, H., ZHANG, W. \& ZHANG, X. 2013. Bank Loan and Political Connection as well as Bank Relation of Listed Company:Empirical Analysis on China's Listed Companies. Technology Economics, 87-94,124.

[13] WANG, W., ZHANG, Z. \& HUANG, Q. 2014. Research on Relationship of R\&D Investment and Firm Performance Based on Moderating Effect of Human Capital of Top Management Team. Forum on Science and Technology in China, 115-120. 